\title{
Family Formation and Structure in Finland
}

\author{
JARL LINDGREN
}

Acting Research Director

The Population Research Institute of Väestöliitto, The Family Federation of Finland

Helsinki, Finland

\begin{abstract}
The article is an overview of the changes in family formation and structure in Finland during the last few decades. The period examined extends from the 1950s until the beginning of the 1990s with the emphasis on the current situation.

The article starts with a look on the changes in union establishment and shows that, on the whole, the age at starting the union has been unchanged if one takes into consideration that a union today starts with premarital cohabitation. There are more divorces than earlier. The dissolution frequency is higher among consensual unions than in marriages. The most common type of family is a family consisting of married parents with children. Living in marriage has decreased among young persons while consensual unions have become more common. The proportion of one-parent families has been almost unchanged during the last two decades. In the 1990s there has been a weak tendency to a growing proportion of families with three children.

The most apparent trend during the following decades will be the rapidly growing number of families without children.
\end{abstract}

Keywords: family formation, consensual unions, marriages, divorce, Finland

\section{A time of change}

During the last few decades society has gone through rapid social and economic development. Norms, values, attitudes and ideals have changed, society has become secularized and individualized. Pluralism and tolerance have grown. Simultaneously economic well-being has increased. As a consequence, the structure of the family has changed rapidly and the forms and content of unions between men and women have become diversified.

Just a few decades ago marriage was an imperative condition for forming a family. Nowadays, new values and attitudes allow several other forms of union between the sexes.

Fewer and fewer marriages are contracted. At the same time more and more couples enter into a consensual union. A growing number of unions end in dissolution. As a consequence, one-parent families have become more common, and it is quite acceptable for a single woman to have a child. The proportion of reconstructed families, with a more many-sided and complicated network of relationships than in the first union, has increased. 
Families are founded later and later in life and fewer children are born. As a consequence of growing longevity there are more and more families without children, i.e. couples living together after their children have left the parental home. However, there is also a growing number of young families who do not intend to have children at all.

The role of mother has changed. Many mothers, even those with small children, are economically active.

More and more individuals live alone. Increasing welfare has enabled more young adults to establish their own households, but also an increasing number of the middleaged and the elderly are living alone.

In the following is an overview of the changes in family formation and family structure in Finland during the last few decades. The period examined extends mainly from the 1950 s until the beginning of the 1990 s with the emphasis on the current situation.

\section{Establishing the union}

From the end of the 1960 s the number of marriages established has gradually declined. This is partly a consequence of declining young age groups but also because consensual unions have become more and more common.

At the end of the 1960 s the total first marriage rate was still more than 900 ; more than 90 percent of all women and men were married (Figure 1). In 1990 the corresponding figures had shrunk to 53 percent for men and 59 for women.

The cohort marriage rates show that the marriage pattern has gradually changed among the cohorts born since the beginning of the 1950 s. The marriage rate has de-

F i g u r e 1. Total first marriage rate in Finland in 1950-1990, per thousand persons.

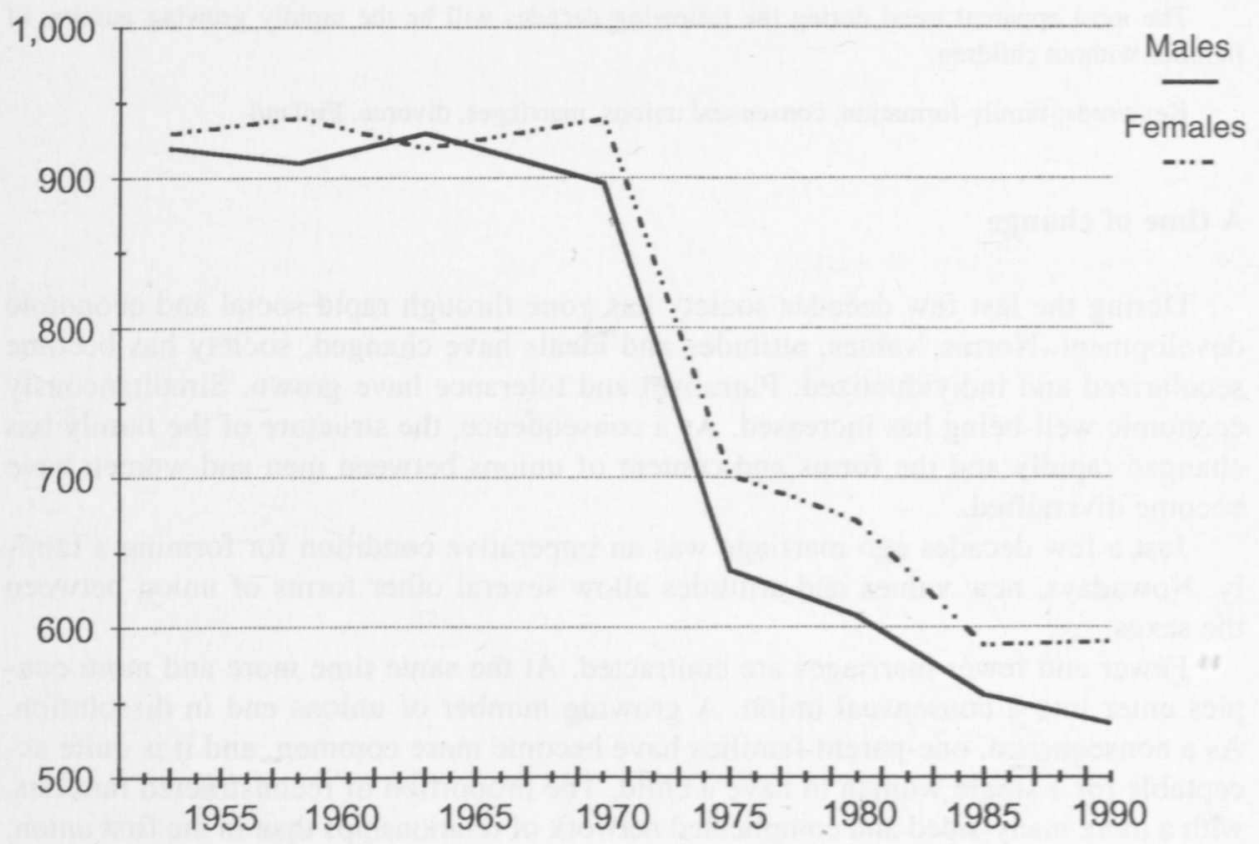

Source: Csernàk 1992, 27. 
clined especially among young people. While 71 percent of the women born in 1950 had contracted a marriage by the age of 25 years, only 52 percent of those born in 1960 had done so. After that the proportion diminished even faster and was as low as 43 percent in the cohort born five years later. If the probability of marrying remains the same as in 1990 , one may predict that roughly one third of all men and women will never marry.

The most important reason for the declining nuptiality especially among young people is the growing custom of establishing a consensual union instead of getting married. However, much less information is available on consensual unions than on marriages. Among those born around 1940 about 18 percent had at sometime in their lives, before reaching the age of 47 , lived in a consensual union (Figure 2). Quite another picture is formed by the younger cohorts. Hence, of those born around 1960 already three-fourths had experienced living together without marriage by the age of 27 . It means that almost 90 percent of this cohort has lived or will live in a consensual union sometime in their lives.

In Finland most consensual unions end in marriage several years later. In the 1950s and 1960s almost all consensual unions ended in marriage. Gradually, in later cohorts, fewer couples get married.

The extramarital cohabitation period lasts longer and longer among young people and more and more couples continue to live in a consensual union. If the frequency of

F i g u re 2. The proportion of couples who have at sometime lived or live now, in 1989 , in a consensual union, by birth cohorts

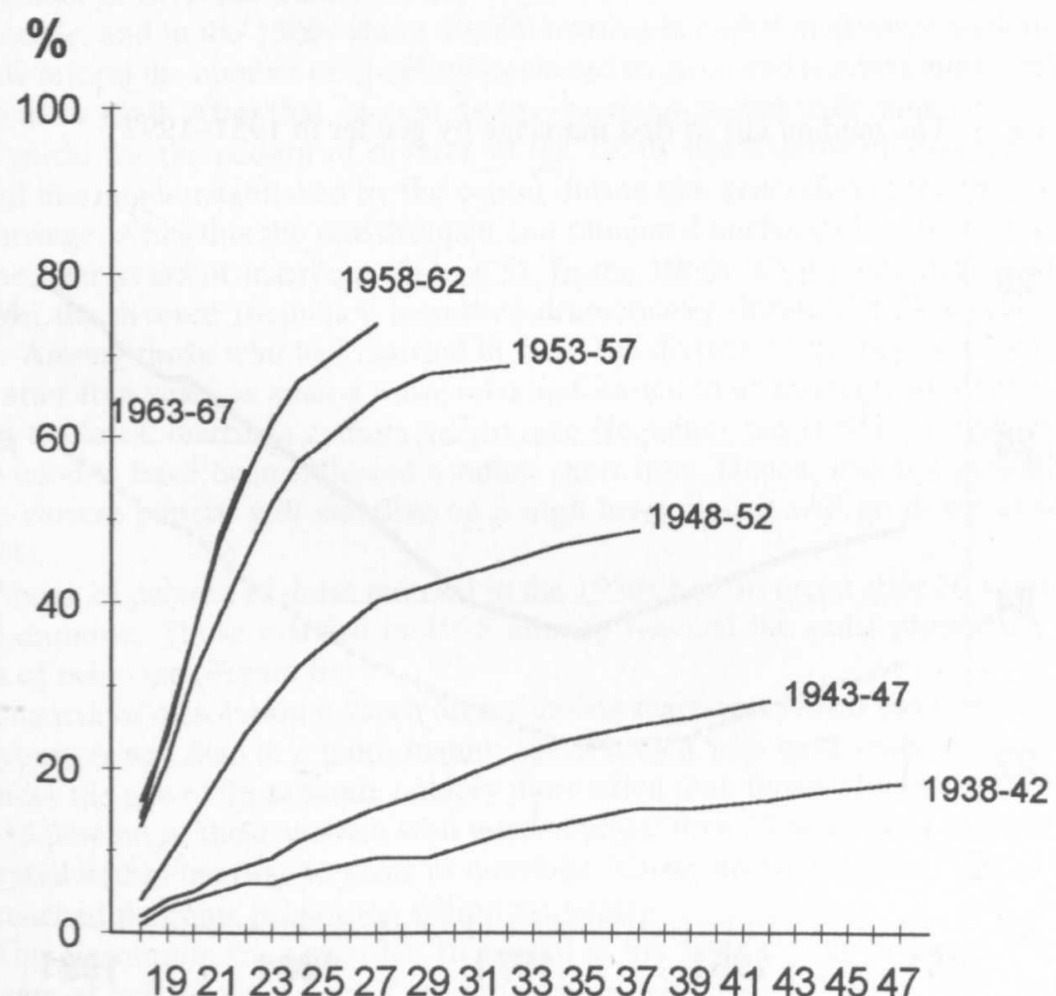

192123252729313335373941434547

Source: Nikander 1992, 38. 
establishing consensual unions remains unchanged during the following decades, one can estimate that at the end of the century only two-thirds of consensual unions started in the 1980 s will end in marriage.

\section{The age at starting the union}

The age at marriage began to decrease in the 1950 s but rose again in the 1970 s. In 1992 the median age at first marriage for males was 28.8 years and for females 26.9 years (Figure 3). The most important reason for the rising age at marriage is the growing proportion of young people who are students or are in vocational training, but also the fact that getting an education takes longer and longer. The increase in studying or pursuing vocational training has especially contributed to the rising age at marriage among women. The custom of living in a premarital relationship has had the same effect. Effective contraception methods also prevent the birth of an unwanted child and a premature conjugal relationship can be avoided.

Usually consensual unions are started earlier than marriages. However, the age at starting a consensual union has also gradually risen, proportionally as much as age at marriage, but is still about two years lower. In the mid-1980s it was 23.5 years (Table 1).

As the major portion of marriages nowadays starts with premarital cohabitation, age at marriage is higher than the age at starting a consensual union. However, a marriage not preceded by premarital cohabitation is contracted practically at the same age as a consensual union.

F i g u r e 3. The median age at first marriage by gender in 1951-1992

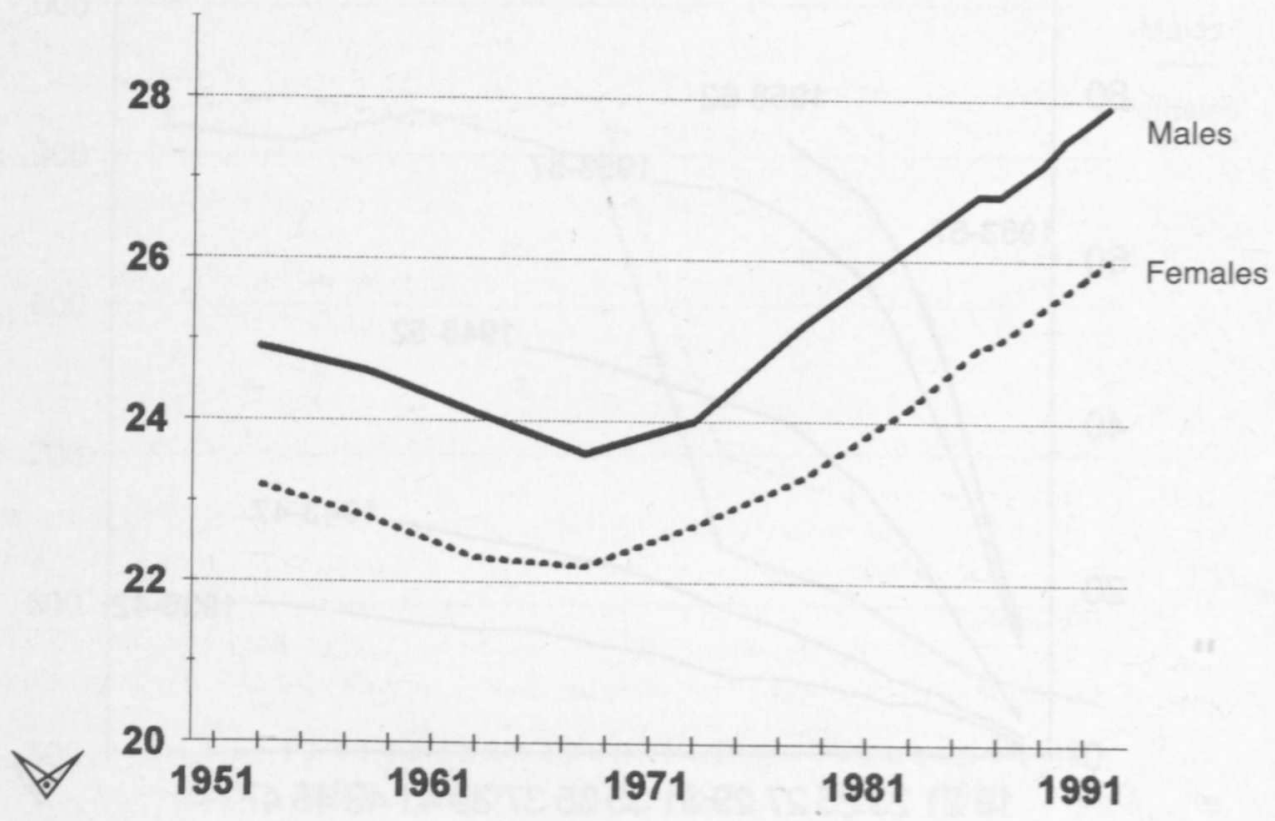

Source: Yearbook 1993. 
$\mathrm{T}$ a b le 1 . The mean age at starting a consensual union among 22-51-year-old women in $1954-1989$

\section{Period}

1954-1964

$1965-1969$

1970-1974

$1975-1979$

1980-1984

Mean age
19.9
20.6
21.2
21.8
23.5

Source: Lindgren, Ritamies and Miettinen 1992, 37.

\section{Dissolution}

Earlier, practically the only reason for marriage dissolution was the death of one of the spouses. During the last few decades divorce has become more and more common. From the beginning of the 1970 s one marriage out of three has ended in divorce, except at the end of the 1980 s when the reform of the law led to a marked increase in dissolutions.

The growth of divorces reflects changes in values, but in particular, the economic liberation of women has been seen as one of the most important reasons for the growth of divorces.

During the $1950 \mathrm{~s}$, the number of divorces remained almost unchanged from one year to another, with annual figures of 3,000-4,000. At the beginning of the $1960 \mathrm{~s}$ the number of divorces started slowly to grow. Growth accelerated during the following decade, and in the 1980s about 10,000 marriages ended in divorce annually. After the law reform the number of dissolutions started to grow and reached more than 14,000 divorces in 1989. After that, though, fewer marriages ended in divorce (Figure 4).

Typical for the pattern of divorce in the 1950 s was a growing divorce rate (percent of marriages established by the cohort during one year) during the first few years of marriage. After this the rate dropped and remained unchanged on a fairly low level for the later years of marriage (Figure 5). In the 1960s the divorce pattern started to change: the divorce frequency increased dramatically during the first years of marriage. Among those who had married in 1970 the divorce frequency was two times as high after five years as among those who had started their marriage in 1960.

In the latest marriage cohorts the divorce frequency has remained high. However, these cohorts have been followed a rather short time. Hence, it is not possible to say if the current pattern will stabilize on a high level or if it will go down as in earlier cohorts.

About 16 percent of those married in the 1950 s had divorced after 30 years of marriage duration. Those married in 1975 already reached the same proportion after 12 years of marriage (Figure 6).

The risk of dissolution is much higher among marriages which have been contracted at a younger age than at a more mature age. Women who have entered into matrimony under the age of 20 separate notably more often than those who have married later. E.g. 15 percent of those women who were younger than 20 when they married in 1970 separated within the first 12 years of marriage. Those who married in 1980 at the same age reached the same proportion within six years.

The dissolution frequency has increased at the same rate as those who married at 20 years of age or older even if the proportions are smaller. Hence, after 30 years 14 percent of the couples married in 1950 had separated. Those married in 1980 already showed the same rate after nine years. 
F i g u r e 4. Number of divorces in 1930-1993

Thousands

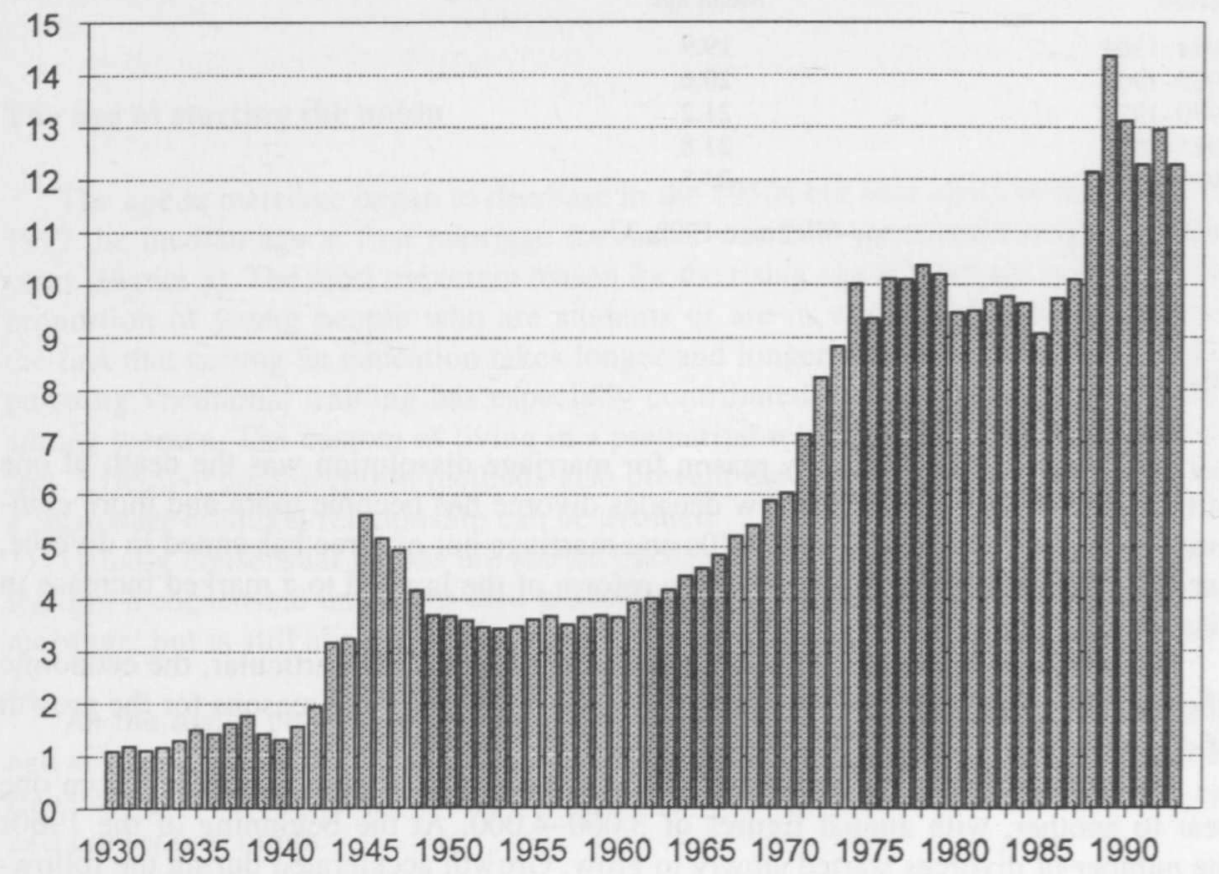

Source: OSF 1930-1993.

F i g u r e 5. Yearly divorce rate of some marriage cohorts from 1950 to 1990

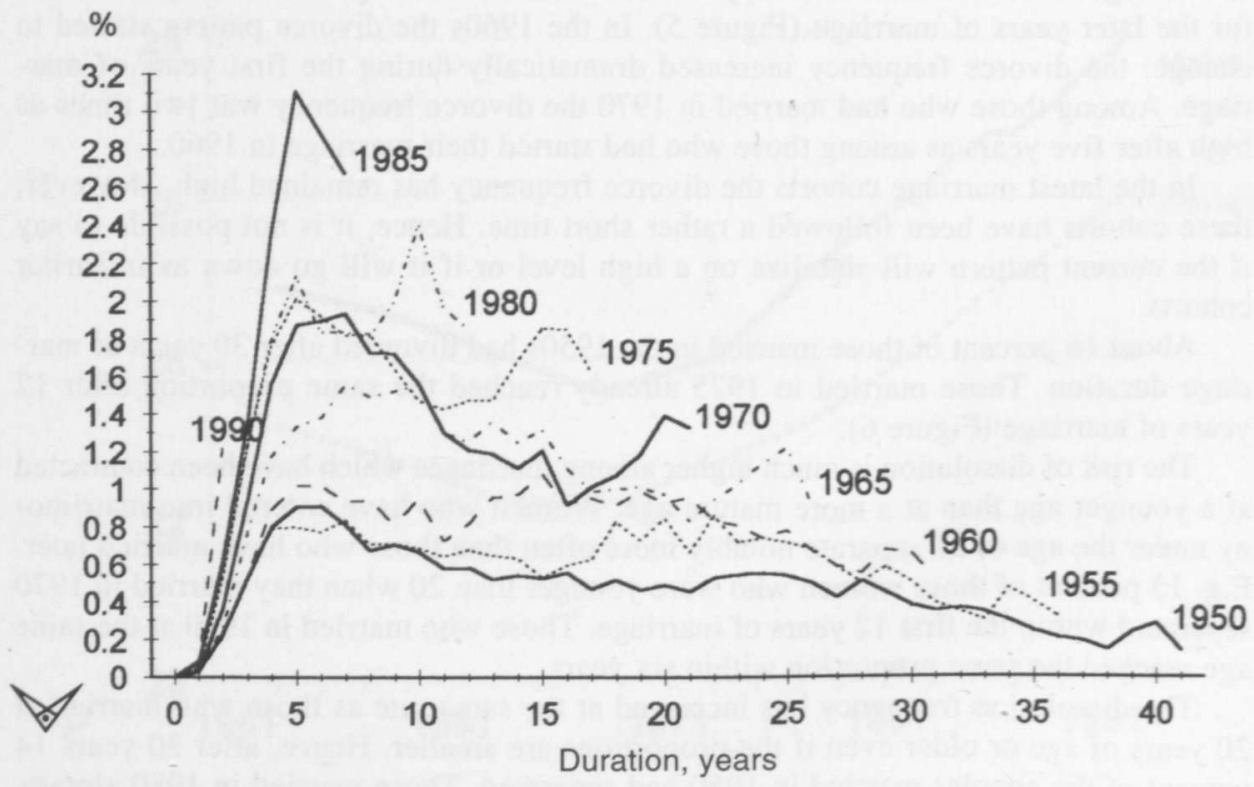

Sources: Lindgren 1986, OSF VI A:149-153, 1991:7, 1992:3, 1993:4, 1994:2 
Fig u re 6. The cumulative divorce rate of some marriage cohorts in 1950-1990

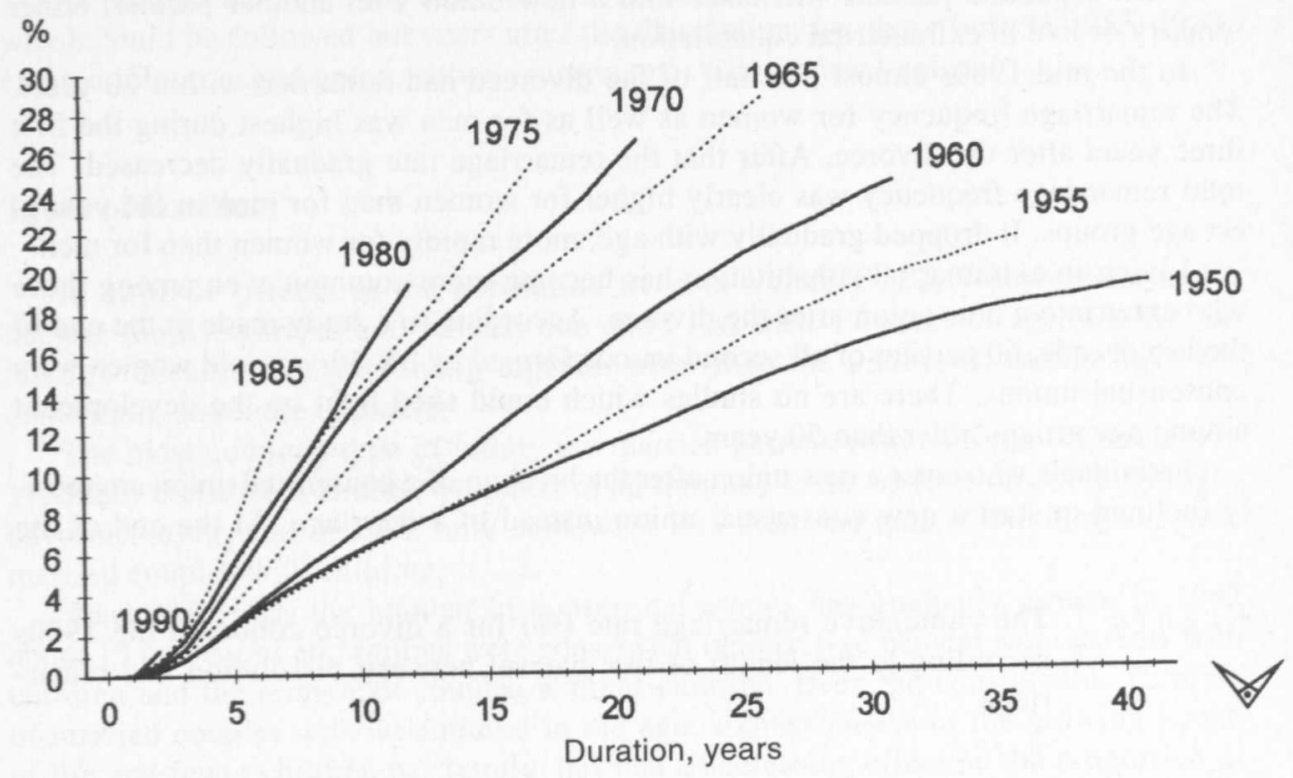

Sources: Lindgren 1986, OSF VI A:149-153, 1991:7, 1992:3, 1993:4, 1994:2.

If the dissolution pattern remains the same as during the last few years, it is estimated that one third of the marriages contracted in the 1980 s will end in a divorce.

As to consensual unions, the dissolution pattern is principally the same as in marriages. Dissolutions increase during the first five-six years and decrease to very few after that. As in marriages the risk of dissolution is greater the earlier the cohabitation is started. The dissolution frequency among women who lived in an extramarital consensual union, which started in 1975-1984, was somewhat lower than among those who got married (Table 2).

T a b l e 2. First consensual unions which had ended in a dissolution by 1989 as a proportion of all first consensual unions, by year of entering the union

Year of entering

$\%$

the union

$\begin{array}{rr}1956-1964 & 9.3 \\ 1965-1969 & 17.8 \\ 1970-1974 & 11.6 \\ 1975-1979 & 19.0 \\ 1980-1984 & 20.4\end{array}$

Source: Lindgren, Ritamies and Miettinen 1992, 40. 


\section{The second union}

Most separated persons will enter into a new union with another partner, either remarry or live in extramarital cohabitation.

In the mid-1980s almost one half of the divorced had remarried within 20 years. The remarriage frequency for women as well as for men was highest during the first three years after the divorce. After that the remarriage rate gradually decreased. The total remarriage frequency was clearly higher for women than for men in the youngest age groups. It dropped gradually with age, more rapidly for women than for men.

Living in extramarital cohabitation has become more common even among those who enter into a new union after the divorce. According to a study made at the end of the last decade, 60 percent of all second unions formed by $35-50$-year-old women were consensual unions. There are no studies which could shed light on the development among age groups older than 50 years.

Individuals who enter a new union after the breakup of a consensual union are mostly inclined to start a new consensual union instead of a marriage. At the end of the

Fig u r e 7 . The cumulative remarriage rate $(\%)$ for a divorce cohort in the 1980 s according to the length of the interval between dissolution and remarriage

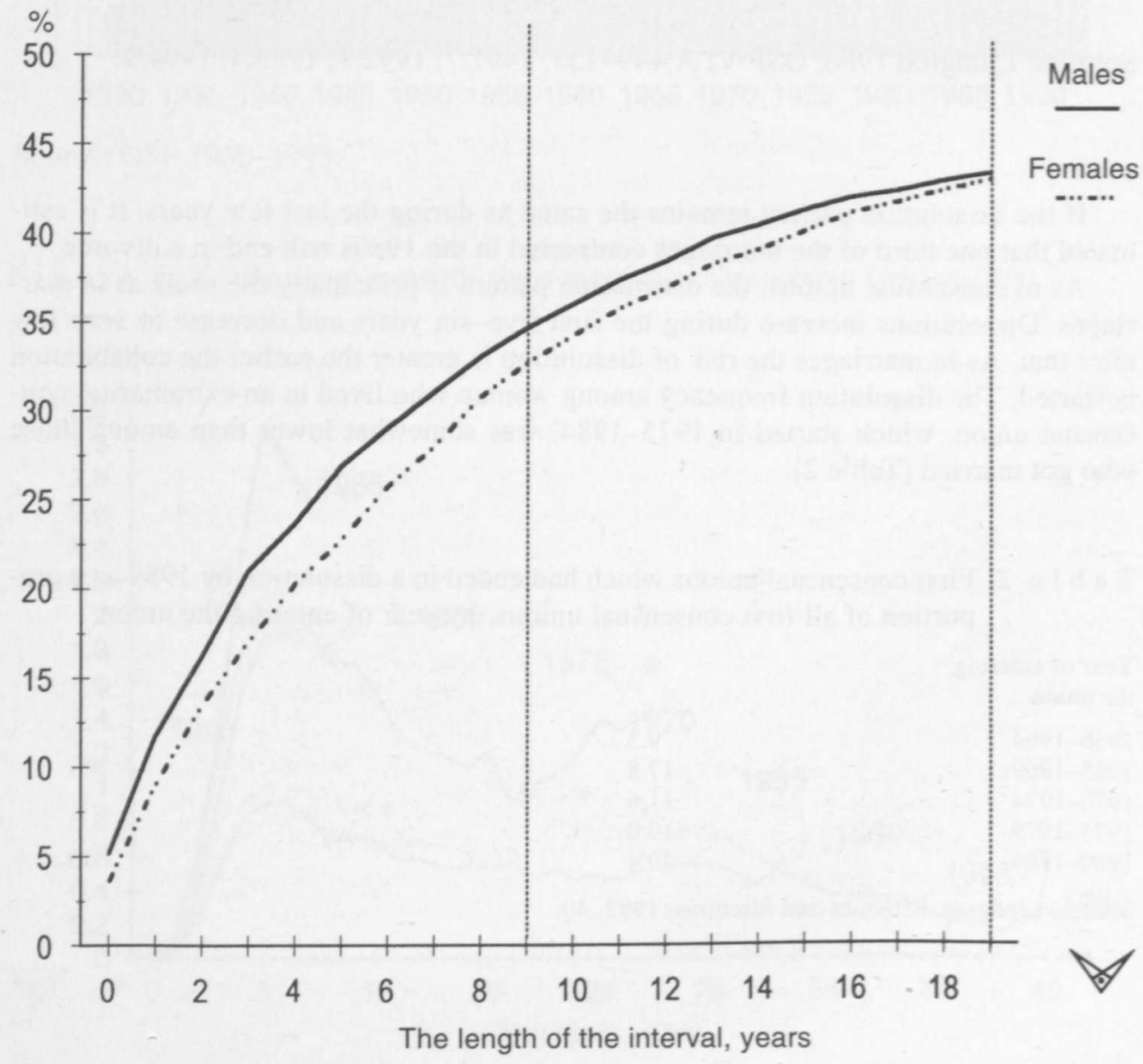

Source: Lindgren and Nieminen 1988. 
1980 s about 60 percent of women went into a new consensual union after the breakup of the first union.

At the end of the 1980s more than 90 percent of the youngest cohort of women which could be followed ten years after the dissolution, i.e. those born in 1953-1957, entered into a second union, either a marriage or a consensual union.

\section{Types of families}

In 199281 percent of the population lived in a family ${ }^{1}$. Forty percent formed a nuclear family: parents and at least one child less then 19 years of age. During the last few decades forms of living together other than the traditional family have become more and more common.

The most common type of family are married parents with children (Figure 8). In 1950 they constituted almost two-thirds of all families. Little by little other family types have increased, and in 1992 only somewhat less than one half of the families were married couples with children.

Since the 1970 s the number of consensual unions has gradually grown. In 1992 about 15 percent of all families were consensual unions; five percent were parents with children and the remainder couples without children. Even the considerable increase of married couples without children in old age, a consequence of the growing length of life and fewer children per family, has had a decreasing effect on the proportion of married couples with children.

Fig u re 8. Families according to the civil status of the parents, 1950-1992

\section{Thousands}

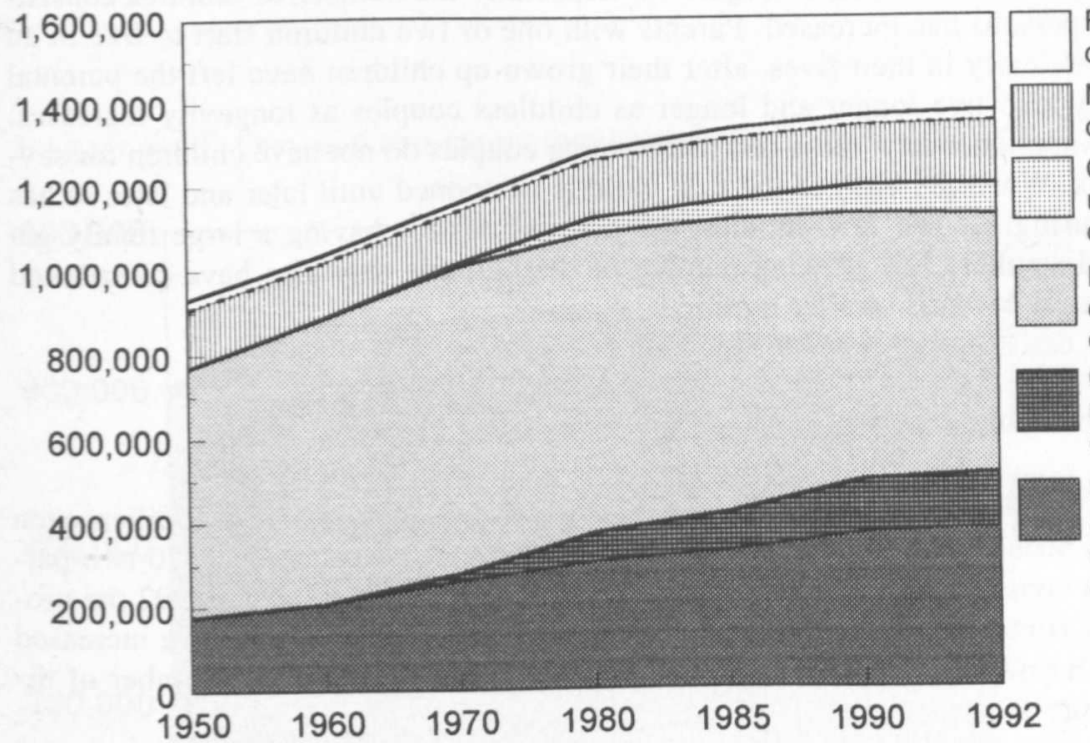

Father and children

Mother and children

Consensual unions with children

Married couples with children

Consensual unions without children

Married couples without children

Source: Statistics Finland 1994, 12.

\footnotetext{
${ }^{1}$ According to the definition used by Statistics Finland, families consist of; - parents with at least one child, living in a marriage or consensual union.

- one parent with at least one child.

- couples without children, living in a marriage or consensual union.
} 
The proportion of one-parent families has been practically unchanged during the last two decades. However, if compared with the situation in 1950 , when aftereffects of the war could still be observed, the proportion of one-parent families is much lower.

Living in marriage has decreased among young persons, while consensual unions have become more common. In 197015 percent of men and 26 percent of women aged 15-24 years lived in a marriage. In 1990 the same proportions had decreased to four and nine. At the same time, the number of married persons in older age groups has increased.

Living in extramarital cohabitation is most common among young people. Almost all unions among persons under 20 years of age are consensual unions. Among persons aged 20-24 two-thirds of all unions are consensual unions. In the next five-year age group the proportion is one third. In older age groups only one tenth live in an extramarital relationship.

Consensual unions are somewhat more usual in cities than in rural municipalities. Persons without education or with a low education cohabit without marriage more often than those with a higher education. Consensual unions are less common among people representing the highest educational level.

The number of persons living separated from their spouse has increased gradually. In mid-1950s only one and a half percent of women older than 15 years were divorced. Among men the proportion was still lower. In 1992 the proportions were nine and seven percent.

During the last two decades remarried persons have composed 10-12 percent of all married people. Among couples living in consensual unions about one third are divorced or have lived earlier in an extramarital companionship with another partner. Among reconstructed families with children one half live in marriage and the other half in a consensual union.

Gradually the size of the family has decreased. Families consisting of two to four persons have become common (Figure 9). Especially the number of families consisting of two persons has increased. Parents with one or two children start to live in an »empty nest» early in their lives, after their grown-up children have left the parental home. They also live longer and longer as childless couples as longevity increases. However, simultaneously, more and more young couples do not have children for several reasons. When the birth of the first child is postponed until later and later as has occurred during the last few decades, the possibilities for having a large family get smaller and smaller. The growing number of dissolutions may also have contributed to the tendency towards smaller families.

\section{Families with children}

Among families with children the most common type are two-parent families, even if there has been a shrinking tendency during the last few decades. In 1970 two-parent families constituted nine out of ten of all families with children. By 1992 the proportion had gone down to three out of four. Families with one parent have increased somewhat during the 1980 s, mostly as a consequence of the growing number of divorces (Figure 10).

In two-parent families children are mostly children that the-parents have had together. Even among reconstituted families one half are families with a common child.

Young families without children usually live in a consensual union. When a child is expected they mostly marry. Hence, only one tenth of families with children live in consensual unions. Even if it is customary to get married when a child is expected, many young mothers remain in extramarital cohabitation even after the child is born. 
Fi g u re 9. Family size in 1950-1990

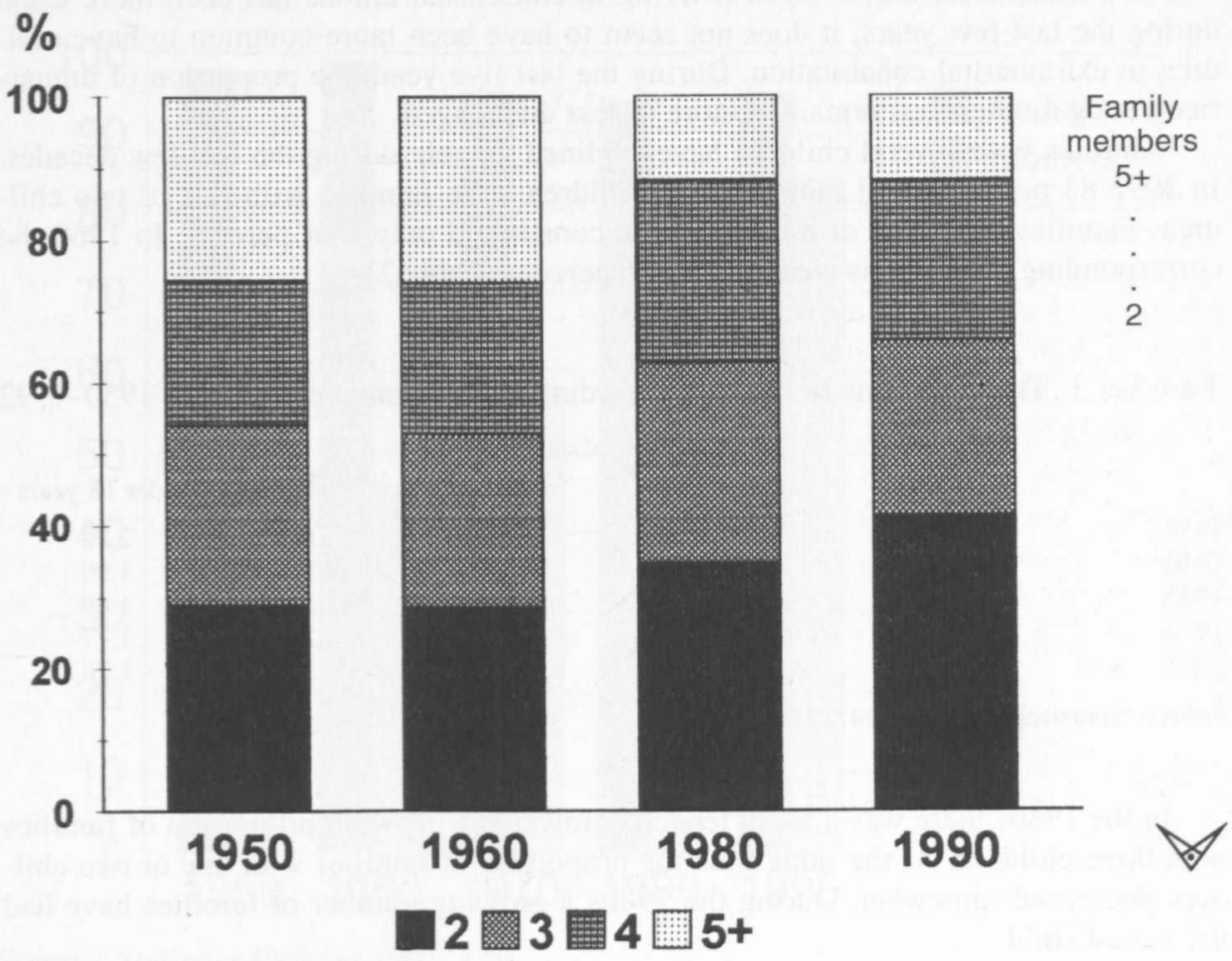

Source: OSF VI A:102, 104, 106; Statistics Finland 1993.

F i g u r e 10. One- and two-parent families with children in 1950-1992

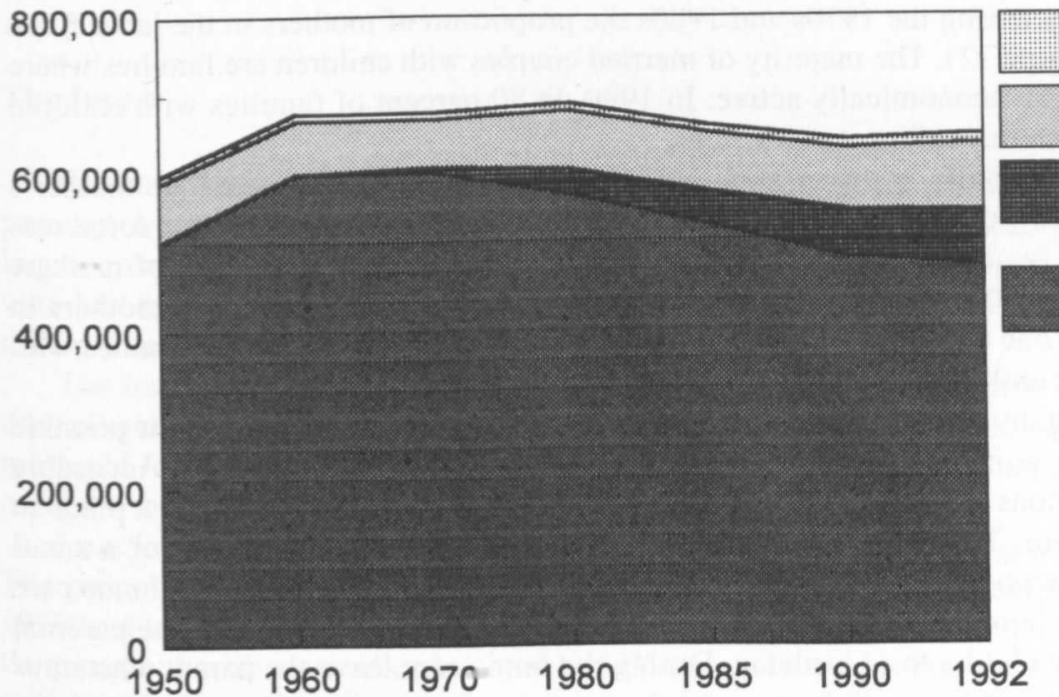

Father and children Mother and children Consensual unions with children Married couples with children

Source: Statistics Finland 1994, 15. 
Among the youngest mothers, those younger than 25 years of age, almost one half live in a consensual union. Even if living in consensual unions has been more usual during the last few years, it does not seem to have been more common to have children in extramarital cohabitation. During the last five years the proportion of unmarried young mothers has remained more or less unchanged.

Families with several children have declined notably during the last few decades. In 199283 percent of all families with children were families with one or two children. Families with four or more children constituted only four percent. In 1960 the corresponding proportions were 68 and 16 percent (Table 3 ).

T a b l e 3. The proportion of families according to the number of children, 1950-1992

\begin{tabular}{cccccc}
\multicolumn{5}{c}{ Mean number of children under } \\
1950 & 1 & 2 & 3 & $4+$ & under 18 years \\
1970 & 39.2 & 28.9 & 15.9 & 16.1 & 2.24 \\
1980 & 42.5 & 32.4 & 14.8 & 9.9 & 1.99 \\
1990 & 48.5 & 38.5 & 10.2 & 2.9 & 1.69 \\
1992 & 44.7 & 39.1 & 12.7 & 3.5 & 1.77 \\
& 44.9 & 38.3 & 13.0 & 3.8 & 1.78
\end{tabular}

Source: Statistics Finland 1994, 21.

In the 1980 s there was a weak tendency towards a growing proportion of families with three children. At the same time the proportion of families with one or two children decreased somewhat. During the 1980 s a growing number of families have had their third child.

The increase of one-parent families is a consequence of the growth of dissolutions and partly also of more births among unmarried mothers, who in some cases are classified as a single parent even if they live in a consensual union.

\section{Both parents economically active}

Especially during the 1970s and 1980s the proportion of mothers in the labor force increased (Figure 11). The majority of married couples with children are families where both parents are economically active. In 1990, in 80 percent of families with children both parents were working outside home.

Earlier, especially in urban municipalities, having children lessened the mother's possibilities to work outside home. The proportion of mothers in the labor force was low in small families, in large families quite rare. Gradually the number of mothers working outside the home increased, and in 1990 more than 80 percent of mothers in families with one or two children were economically active. However, in families with three or more children the mother still mostly stays at home.

The gradually extended system of institutionalized child care has made it possible for a growing number of mothers with children to be economically active. According to the regulations which took full effect in 1990 , every child has a right to a place in public day care. The growing interest in staying at home and taking care of a small child is a consequence of the right to choose between children's day care or home care leave. During home care leave the mother or father can stay at home after the parental leave until the child's third birthday. During the home care leave the parent who stays at home is entitled to an allowance and the employer is not allowed to terminate employment during this time. Part-time jobs which in many countries are used to enable 
Fig u re 11 . The proportion of economically active mothers and fathers in 1950 1990

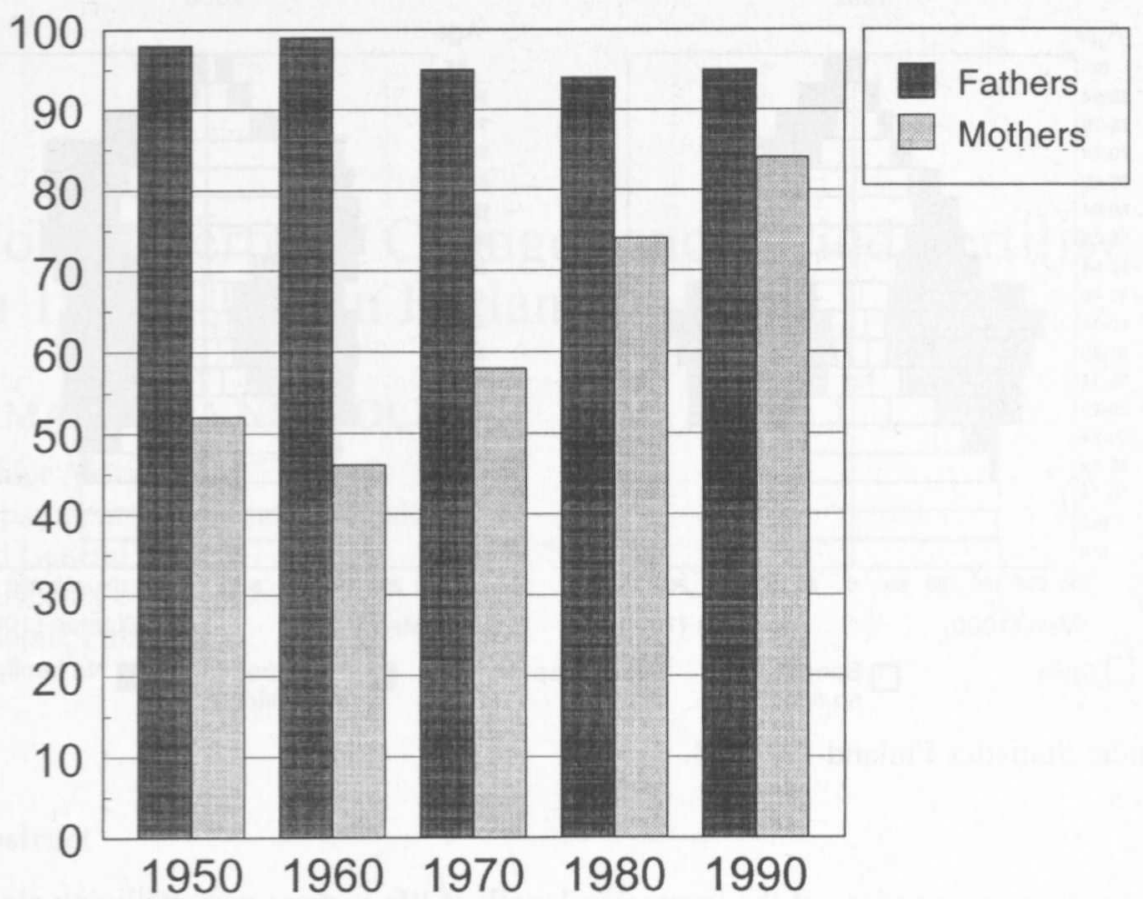

Source: Statistics Finland 1994, 130.

the mother to work outside the home are not very popular in Finland, mostly because of low payment and poor social security.

In 199155 percent of mothers with a child younger than three years were in labor force while in the 1950 s the corresponding proportion was as high as three-fourths.

\section{The future}

Future demographic development will affect family structure. According to the population projection made by Statistics Finland the main change during the following two or three decades is growing longevity. The growing length of life together with low fertility, which is expected to be on the same level as in the 1980s: 1.8 children per mother, will affect family structure in many ways.

The most apparent result is the rapidly growing number of families without children (Figure 12). When men and women live longer and fertility is low there will be more old families without children. Probably there will even be a small but continuous growth of younger families who do not want to have children.

Low fertility results in less children and gradually in less families with children. The proportion of families with children is estimated to decrease from 52 percent in 1990 to 44 percent in 2020 . Consensual unions with children will decrease only a little compared with married couples with children which means that consensual unions will tend to be an increasingly common form of union among families. The proportion of one-parent families will remain more or less unchanged. 
F i g u r e 12 . Finland's population by type of family in 1992 and 2020.
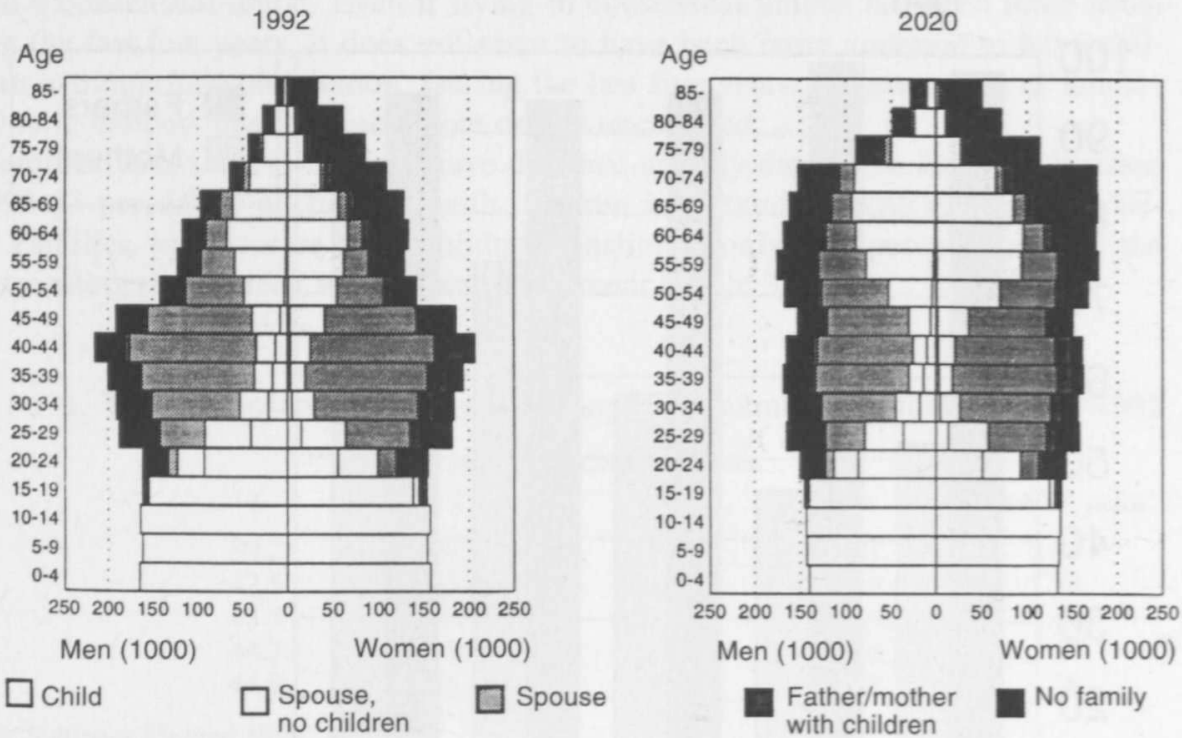

Source: Statistics Finland 1994, 53.

Another consequence of the increasing length of life is more persons living alone, especially more men as mens' length of life is estimated to grow somewhat faster than that of women.

More visible than the transition in population structure is the change of the shape of the population pyramid. At present the large age groups born after the Second World War are middle-aged and form a bulge on the pyramid. In a few decades they will constitute the elderly. The shape of the pyramid will change from a more or less pyramidal one towards a rectangular one.

\section{References}

Csernàk, Magdolna. 1992. Patterns of first marriage in Finland and Hungary: a comparative study. Yearbook of Population Research in Finland 30:18-32.

Lindgren, Jarl. 1986. Recent divorce trends and patterns in Finland. Yearbook of Population Research in Finland 24:72-84.

Lindgren, Jarl and Mauri Nieminen. 1988. Uudelleen avioituminen (Remarriage). Väestöntutkimuslaitoksen julkaisusarja D, No. 21. Helsinki: Väestöntutkimuslaitos, Väestöliitto

Lindgren, Jarl, Marketta Ritamies and Anneli Miettinen. 1992. Consensual unions and their dissolution among Finnish women born in 1938-1969. Yearbook of Population Research in Finland 30:3343.

Nikander, Timo. 1992. Naisen elämänkulku ja perheellistyminen : the woman's life course and the family formation. Population 1992:1. Helsinki: Statistics Finland.

OSF (Official Statistics of Finland). 1930-1993. Vital Statistics VI, Nos. 92-100; Population Structure and Vital Statistics VI A, Nos. 101- 153; Vital Statistics, Population 1990:7, 1991:7, 1992:3, 1993:4, 1994:2,7. Helsinki: Statistics Finland.

Statistics Finland. 1993. Population Census 1990, Vol. 3: Household-Dwelling Units and Families. Helsinki: Statistics Finland.

Statistics Finland. 1994. Suomalainen perhe (The Finnish Family). Väestö 1994:5. Helsinki 1994.

Yearbook (Yearbook of Population Research in Finland). 1993. Volume 30. 